\title{
RESEARCH OF THE THERMAL DESORPTION PROCESSES IN OXIDE MIXTURES AT LASER EFFECT
}

\author{
V.V. Katrechko ${ }^{1}$, D.V. Vinnikov ${ }^{1}$, V.B. Yuferov ${ }^{1}$, V.O. Ilichova ${ }^{I}$, A.S. Svichkar ${ }^{1}$, \\ I.V. Buravilov', V.D. Timofeev", O.G. Bobrov ${ }^{2}$ \\ ${ }^{1}$ National Science Center "Kharkov Institute of Physics and Technology”, Kharkiv, Ukraine; \\ ${ }^{2}$ Military Institute of Tank Forces National Technical University \\ "Kharkiv Polytechnic Institute", Kharkiv, Ukraine \\ E-mail:v.yuferov@kipt.kharkov.ua
}

To investigate the physical-chemical processes occurring during the heating stage of spent nuclear fuel magneto plasma reprocessing a study of thermal desorption of oxides and oxide mixtures as SNF simulators under the influence of stationary laser radiation are being studied. Preliminary experiments were carried out. X-ray diffraction and energy dispersive X-ray microanalysis of the film deposited on the substrate after laser influence on a mixture of $\mathrm{B}_{2} \mathrm{O}_{3} / \mathrm{ZrO}_{2}$ oxides have been performed.

PACS: $28.41 \mathrm{Kw}$

\section{INTRODUCTION}

Magneto plasma reprocessing of spent nuclear fuel (SNF), which is an alternative to the radiochemical methods involves the use of physical methods for a cleanup of a multicomponent composition of spent fuel from fission products (FPs) at heating, ionization and plasma rotating in crossed $\mathrm{E} \times \mathrm{B}$ fields [1].

At the stage of SNF heating $(\sim 2800 \mathrm{~K})$ due to the difference of physical-chemical properties (melting point, vapor pressure) up to $75 \%$ FPs can be removed [2]. These are mainly gases, volatile compounds and oxides with a low binding energy.

Investigation of thermal desorption processes for oxide compounds and their mixtures at heating stage will allow us to study the features of SNF multicomponent composition to reduce energy losses during conversion to plasma.

To accelerate the process of thermal desorption at the stage of SNF heating, it is advisable to preliminarily grinding the working substance to a micropowder with particle sizes of $10 \ldots 50 \mu \mathrm{m}$ [3].

Micropowder heating under atmospheric conditions can be accomplished using a laser. Knowing the specific power of the light flux onto the surface of the material, we can estimate the temperature to which the micropowder will be heated according StefanBoltzmann law:

$$
Q=\varepsilon \sigma \cdot T^{4},
$$

where $\varepsilon$ is the emissivity of the grey body; $\sigma-$ StefanBoltzmann constant; $T$ - temperature; $Q-$ is the amount of energy emitted by an object per unit area.
When a laser beam hits the surface of individual particles, the radiation partially reflects and partially penetrates deeper, where it is absorbed and released in the form of heat. At low power densities of the absorbed laser radiation $\left(q \leq 10^{4} \mathrm{~W} / \mathrm{cm}^{2}\right)$, the laser action on the material is associated with the processes of melting, evaporation, and ablation [4].

\section{PRELIMINARY EXPERIMENTS}

It is advisable to carry out the experiments on the study of thermal desorption with non-radioactive substances that are simulators of nuclear material. Since uranium oxide fuel is widely used as fuel in power reactors, it isadvisable to choose oxides, for example, zirconium oxide $\left(\mathrm{ZrO}_{2}\right)$ and boron oxide $\left(\mathrm{B}_{2} \mathrm{O}_{3}\right)$. In the imitation experiments the carbonates of rare earth elements can be used, for example, neodymium carbonate $\left(\mathrm{Nd}_{2}\left(\mathrm{CO}_{3}\right)_{3}\right)$ to produce neodymium oxide $\left(\mathrm{Nd}_{2} \mathrm{O}_{3}\right)$, which is present in $\mathrm{SNF}$ and has similar properties with uranium dioxide $\left(\mathrm{UO}_{2}\right)$. For obtaining of barium oxide $(\mathrm{BaO})$ barium sulfate $\left(\mathrm{BaSO}_{4}\right)$ can be used (Table 1).

For micropowders heating carbon dioxide $\mathrm{CO}_{2} \mathrm{PL}$ 1600 laser with a maximum power of the continuouswave $W_{\max }=80 \mathrm{~W}$. When the efficiency of a carbon dioxide laser is about $20 \%$, the total energy consumptions at $400 \mathrm{~W}$. The beam diameter was $2 \mathrm{~mm}$. The duration of exposure time was $30 \ldots 60 \mathrm{~s}$. In the experiments, the power was adjusted from 10 to $100 \%$.

Chemical compounds used in the experiments and their properties

\begin{tabular}{|c|c|c|c|c|}
\hline Compound & amu & $T_{\text {m.p. }}, \mathrm{K}$ & $T_{\text {b.p }}, \mathrm{K}$ & $T_{\text {dec }}, \mathrm{K}$ \\
\hline $\mathrm{B}_{2} \mathrm{O}_{3}$ & 69 & 753 & 2133 & - \\
\hline $\mathrm{BaSO}_{4}$ & 233 & 1850 & - & $>1850$ \\
\hline $\begin{array}{c}\mathrm{BaO} \text { (decomposition } \\
\text { product) }\end{array}$ & 153 & 2196 & 2273 & - \\
\hline $\mathrm{ZrO}_{2}$ & 123 & 2988 & 4573 & - \\
\hline $\mathrm{Nd}_{2}\left(\mathrm{CO}_{3}\right)_{3}$ & 468 & - & - & $800 \ldots 1150$ \\
\hline $\begin{array}{c}\mathrm{Nd}_{2} \mathrm{O}_{3} \text { (decomposition } \\
\text { product) }\end{array}$ & 336 & 2273 & 4033 & - \\
\hline
\end{tabular}


When the laser beam hits the normal to the surface where the working micropowder is located, the maximum specific power of the laser radiation is:

$$
Q=W_{\max } / \pi \cdot r^{2} \text {. }
$$

In our case $Q=2.54 \cdot 10^{3} \mathrm{~W} / \mathrm{cm}^{2}$.

Substituting the value of $Q$ in relation (1), we can determine the maximum temperature of thermal radiation from the surface of the working substance. We use the experimental data of $\varepsilon$ for $\mathrm{ZrO}_{2}$ [5] at temperatures $>2000 \mathrm{~K}$. Note that for $T=2000 \ldots 2400 \mathrm{~K}$ $\varepsilon$ corresponds to a value of $0.8 \ldots 0.9$ and with a further increase in temperature is in the same range that is shown in Fig. 1. For these values of $\varepsilon$ and $W_{\max }$ we can determine $T_{\max }=4500 \ldots 4800 \mathrm{~K}$ from relation (1).

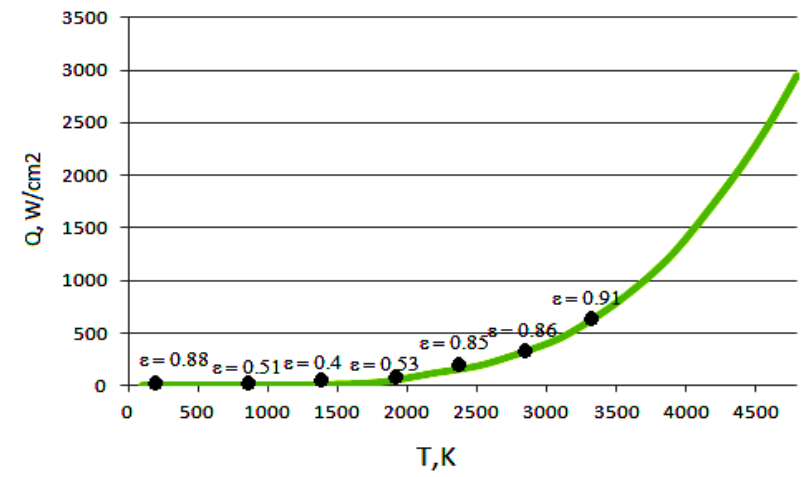

Fig. 1. Dependence of the radiation specific power on the temperature of $\mathrm{ZrO}_{2}$

When boron oxide $\mathrm{B}_{2} \mathrm{O}_{3}$ is irradiated (Fig. 2) by a laser, active evaporation is observed followed by $\mathrm{B}_{2} \mathrm{O}_{3}$ deposition on the substrate. After $30 \mathrm{~s}$ of the laser beam effect at maximum power ablation of the working substance and appearance of vapor were visually observed. The vapor effect can be explained by the storage conditions of the initial samples of boron oxide in atmospheric conditions. Boron oxide interacts with water vapor, which is part of the air atmosphere, and under laser irradiation, the evaporation of the material is accompanied by a vapor phase.

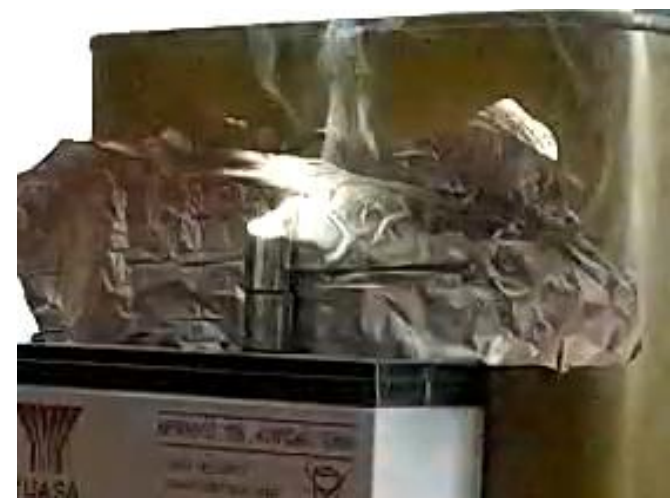

Fig. 2. $\mathrm{B}_{2} \mathrm{O}_{3}$ micropowder under laser beam effect

At stationary laser irradiation of zirconium oxide $\left(\mathrm{ZrO}_{2}\right)$, the intense luminescence and local heating of the working substance at the site of impact of the laser beam was observed (Fig. 3).

A micropowder of $\mathrm{BaSO}_{4}$ was used for $\mathrm{BaO}$ obtaining that upon heating by the laser beam is decomposed into three components according to the chemical reaction:

$$
\mathrm{BaSO}_{4} \rightarrow \mathrm{BaO}+\mathrm{SO}_{2}+\mathrm{O}_{2}(\sim 1870 \mathrm{~K}) .
$$

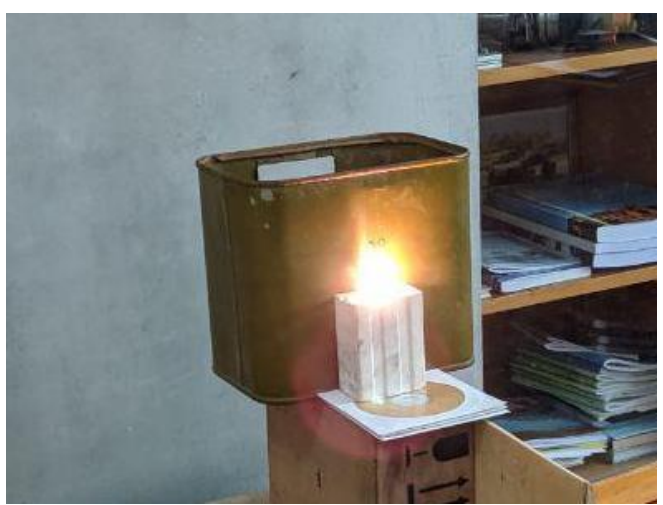

Fig. 3. $\mathrm{ZrO}_{2}$ micropowder under laser beam effect

In this case, $\mathrm{SO}_{2}$ reacts with atmospheric components and volatilizes.

By analogy with $\mathrm{BaSO}_{4}$ laser beam effect on the carbonate of neodymium $\left(\mathrm{Nd}_{2}\left(\mathrm{CO}_{3}\right)_{3}\right)$ allows to obtain neodymium oxide $\left(\mathrm{Nd}_{2} \mathrm{O}_{3}\right)$ at decomposition of neodymium carbonate. It was shown in [6] that at temperatures of $\sim 800$ and $\sim 1100 \mathrm{~K}$, under atmospheric conditions, neodymium carbonate is converted to neodymium oxide $\left(\mathrm{Nd}_{2} \mathrm{O}_{3}\right)$ with the release of carbon dioxide and an intermediate product of oxycarbonate. The process is described by the following chemical reactions:

$$
\begin{gathered}
\mathrm{Nd}_{2}\left(\mathrm{CO}_{3}\right)_{3} \rightarrow \mathrm{Nd}_{2} \mathrm{O}_{2} \mathrm{CO}_{3}+2 \mathrm{CO}_{2} \uparrow,(\sim 800 \mathrm{~K}), \\
\mathrm{Nd}_{2} \mathrm{O}_{2} \mathrm{CO}_{3} \rightarrow \mathrm{Nd}_{2} \mathrm{O}_{3}+\mathrm{CO}_{2} \uparrow,(\sim 1100 \mathrm{~K}) .
\end{gathered}
$$

Figs. 4 and 5 show the result of chemical reactions with sulfur and carbon traces in the $\mathrm{BaSO}_{4}$ and $\mathrm{Nd}_{2}\left(\mathrm{CO}_{3}\right)$ samples, respectively, after laser irradiation during $30 \mathrm{~s}$.

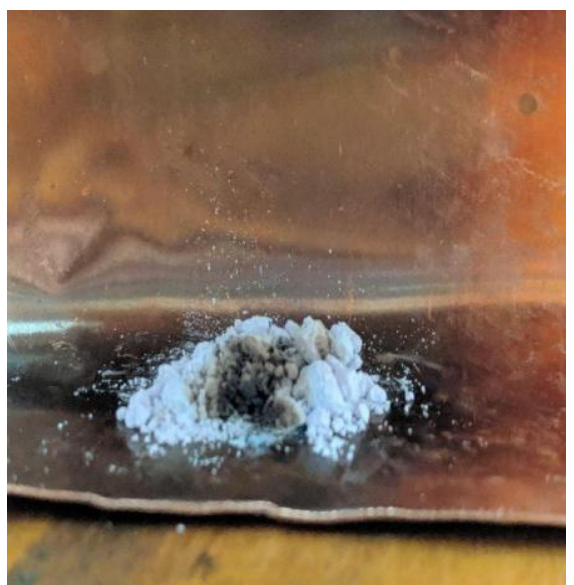

Fig. 4. $\mathrm{BaSO}_{4}$ sample after laser irradiation

To study the possibility of separating a component from a mixture of oxides by difference in vapor pressure during thermal desorption the $\mathrm{B}_{2} \mathrm{O}_{3} / \mathrm{ZrO}_{2}$ mixture was used (Fig. 6). The vaporized substance after heating by laser irradiation for $30 \mathrm{~s}$ (at a given power density of $300 \ldots 400 \mathrm{~W} / \mathrm{cm}^{2}$, which corresponds to the thermal radiation from the surface at the temperature of $\sim 2800 \mathrm{~K}$ (see Fig. 1)) was deposited on a copper substrate for subsequent film diagnostics. 


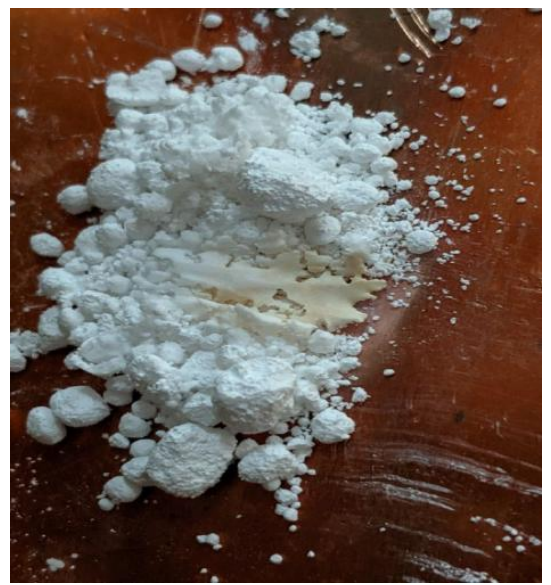

Fig. 5. $\mathrm{Nd}_{2}\left(\mathrm{CO}_{3}\right)_{3}$ sample after laser irradiation

To determine the phase composition of the film an $\mathrm{X}$-ray diffraction analysis was performed (Table 2). The complexity of the analysis was the formation of a film with an insufficient thickness of $1 \ldots 3 \mu \mathrm{m}$. The presence of lines corresponding to the zirconium oxide were not found in this analysis. This may indicate a lack of sensitivity of the method at a small amount of evaporated substance. However, the traces of triclinic modification of orthoboric acid (boron in combination with oxygen and hydrogen (Fig. 7)) were found, that, apparently, was the result of the interaction of boron with atmospheric components.

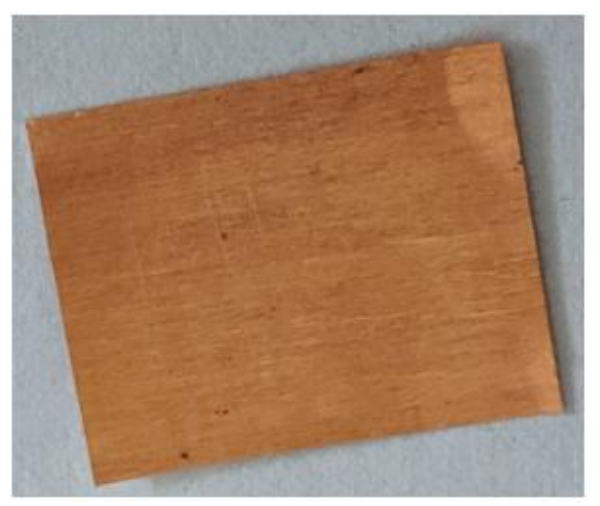

$a$

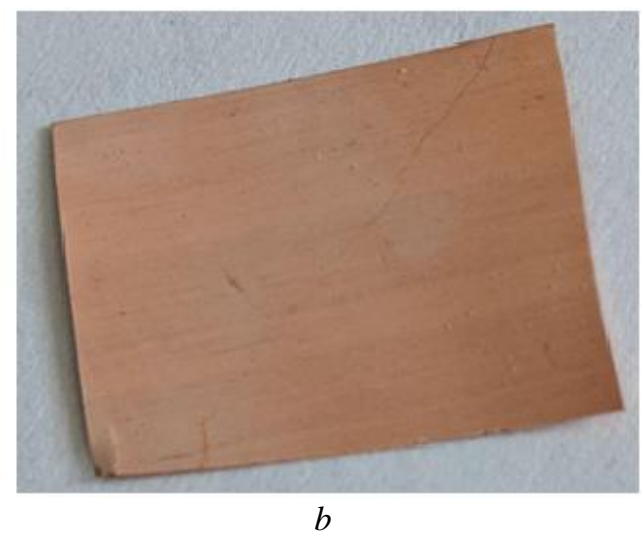

Fig. 6. Photo of a copper substrate: copper substrate (a), copper substrate after laser influence on $\mathrm{B}_{2} \mathrm{O}_{3} / \mathrm{ZrO}_{2}$ mixture (b)

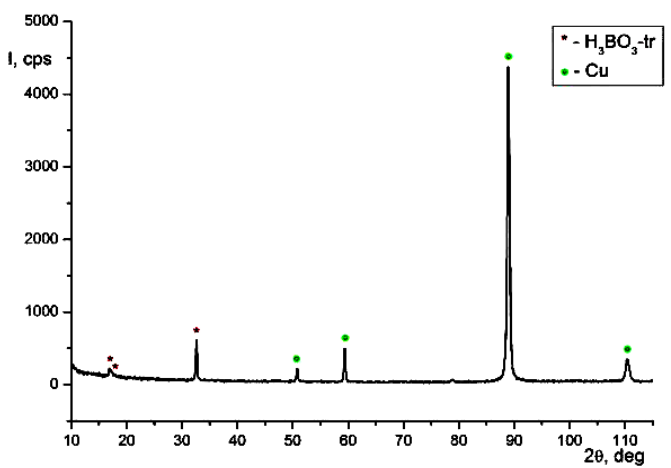

Fig. 7. Diffraction pattern of the copper substrate after laser influence on $\mathrm{B}_{2} \mathrm{O}_{3} / \mathrm{ZrO} \mathrm{O}_{2}$ mixture

Table 2

The results of the X-ray diffraction analysis

\begin{tabular}{|c|c|}
\hline Phase & Lattice parameters, $\AA$ \\
\hline & $a=7.04 ; b=7.05 ;$ \\
& $c=6.58 ;$ \\
$\mathrm{H}_{3} \mathrm{BO}_{3}$-tr & $\alpha=92.60^{\circ} ; \beta=101.17^{\circ} ;$ \\
& $\gamma=119.83^{\circ}$ \\
\hline $\mathrm{Cu}$ & $a=3.615$ \\
\hline
\end{tabular}

Additionally, an energy dispersive X-ray (EDX) microanalysis of the deposited film (Figs. 8, 9 and Table 3) shows the presence of boron oxide polycrystals with a maximum particle size of $\sim 5 \mu \mathrm{m}$.
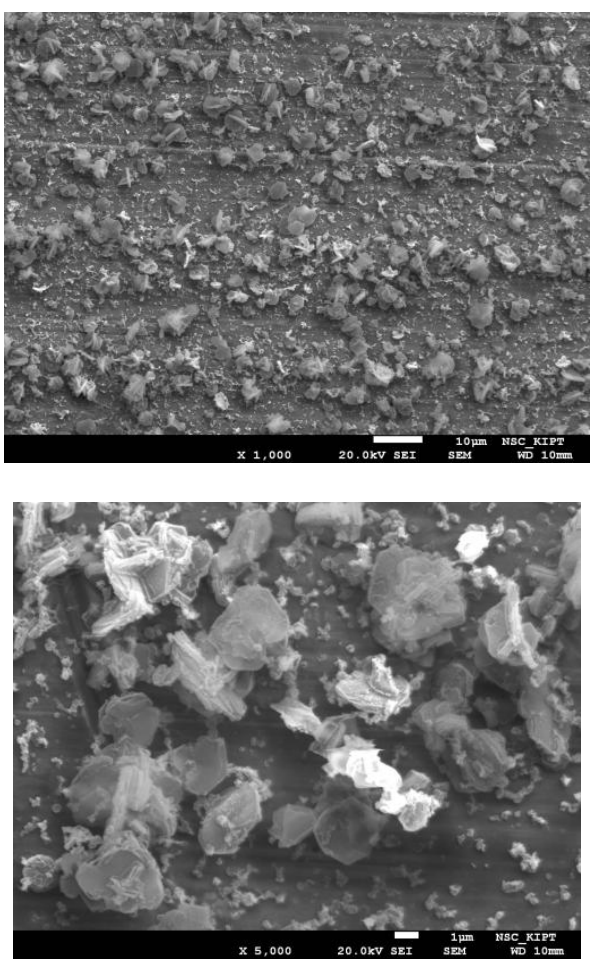

Fig. 8. Results of EDX analysis of a mixture of $\mathrm{B}_{2} \mathrm{O}_{3} / \mathrm{ZrO}_{2}$ at various scales

Thus, separation of $\mathrm{B}_{2} \mathrm{O}_{3}$ component from the $\mathrm{B}_{2} \mathrm{O}_{3} / \mathrm{ZrO}_{2}$ mixture under laser effect with specific power range of $300 \ldots 400 \mathrm{~W} / \mathrm{cm}^{2}$ (or $10 \ldots 15 \%$ of $W_{\max }$ ) during thermal desorption process due to difference of physical-chemical properties was performed. 


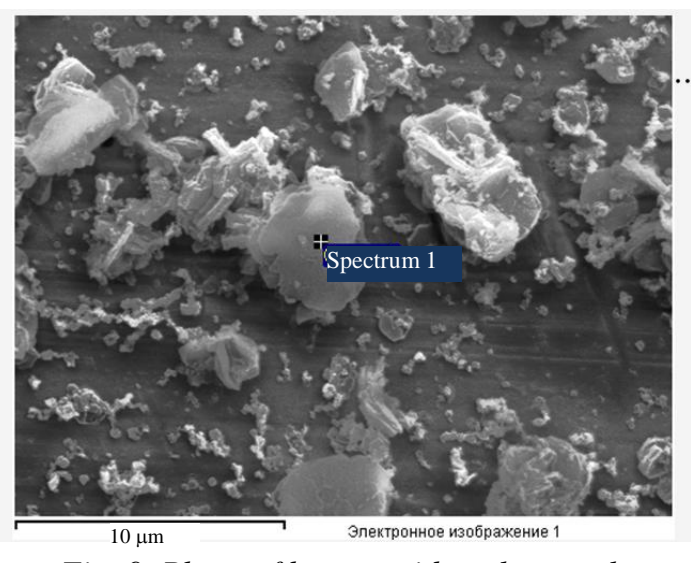

Fig. 9. Photo of boron oxide polycrystals

Table 3

Results of EDX analysis. Spectrum 1

\begin{tabular}{|c|c|c|}
\hline Element & wt. \% & at. \% \\
\hline $\mathrm{B}$ & 36.63 & 46.10 \\
\hline $\mathrm{O}$ & 63.37 & 53.90 \\
\hline
\end{tabular}

\section{SUMMARY}

- The use of a stationary-power $\mathrm{CO}_{2}$ laser for heating and thermal desorption of $\mathrm{B}_{2} \mathrm{O}_{3} / \mathrm{ZrO}_{2}$ mixture with subsequent deposition of the film on a substrate is considered. X-ray diffraction analysis of the film deposited on the substrate does not show the presence of lines corresponding to the lines of zirconium oxide. EDX analysis of the film deposited on the substrate show the formation of polycrystals of boron oxide with sizes of $1 \ldots 5 \mu \mathrm{m}$.

- Preliminary experiments with a mixture of oxides showed that under laser irradiation of a given power it is possible to remove the target components from oxide mixture (to clean up mixture from the impurities) during thermal desorption process due to vapor pressure difference.

- An analysis of the results indicates that it is necessary to take into account the influence of atmospheric conditions and the interaction of the working substance with air components under laser effect.

\section{ACKNOWLEDGEMENTS}

Special thanks for providing equipment and assistance in the experiments to team of co-authors of research laboratory (armored weapons and military equipment) of the Faculty of Military Training of the National Technical University "Kharkiv Polytechnic Institute" in person V.D. Timofeev and O.G. Bobrov.

\section{REFERENCES}

1. В.Б. Юферов, В.В. Катречко, В.О. Ильичева, С.В. Шарый, А.С. Свичкарь, М.О. Швец, Е.В. Муфель, А.Г. Бобров. Развитие концепции многостадийной очистки отработавшего ядерного топлива от продуктов деления физическими методами // ВАНТ. Серия «Вакуум, чистые материаль, сверхпроводники». 2018, №1(113), с. 118-126.

2. V.B. Yuferov, V.V. Katrechko, A.S. Svichkar, S.V. Shariy, T.I. Tkachova, E.V. Mufel, V.O. Ilichova, A.Yu. Pakhomov. Problems of impuruties deducing from multicomponent media at thermal heating, ionization and rotation of plasma in crossed fields // Problems of Atomic Science and Technology. 2016, N 1(101), p. 124-130.

3. Д.В. Винников, В.В. Катречко, Н.А. Шульгин, В.Б. Юферов, В.И. Соколенко, В.И. Ткачев, А.Н. Пономарев, И.В. Буравилов. Измельчение материалов, моделирующих ОЯТ для магнитоплазменного разделения // ВАНТ. Серия «Физика радиационных повреждений $u$ радиационное материаловедение». 2016, №4(104), с. 54-57.

4. М.Н. Либенсон, Е.Б. Яковлев, Г.Д. Шандыбина. Взаимодействие лазерного излучения с вещуеством (силовая оптика). Ч. ІІ. Лазерный нагрев и разрушение материалов: Учебное пособие / Под общ. ред. В.П. Вейко. СПб: НИУ ИТМО, 2014, с. 50.

5. Г.В. Самсонов. Теплофизические свойства твердых веществ. М.: «Наука», 1971, с. 98.

6. В.А. Кочедыков, И.Д. Закирьянова, И.В. Корзун. Исследование термического разложения продуктов взаимодействия оксидов Р3Э с компонентами атмосферы воздуха // Аналитика $u$ контроль. 2005, т. 9, №1, с. 58-63.

Статья поступила в редакциию 18.11.2019 2.

\section{ИССЛЕДОВАНИЕ ТЕРМОДЕСОРБЦИИ ОКСИДНЫХ СМЕСЕЙ ПРИ ЛАЗЕРНОМ ВОЗДЕЙСТВИИ}

\section{В.В. Катречко, Д.В. Винников, В.Б. Юферов, В.О. Ильичева, А.С. Свичкарь, И.В. Буравилов, \\ В.Д. Тимофеев, А.Г. Бобров}

Для изучения физико-химических процессов, происходящих на стадии нагрева магнитоплазменной переработки отработавшего ядерного топлива (ОЯТ), проводится исследование термодесорбции оксидов и оксидных смесей - имитаторов ОЯТ при воздействии стационарного лазерного излучения. Проведены предварительные эксперименты, выполнены рентгенодифракционный и энергодисперсионный рентгеновский микроанализы пленки, осажденной на подложку при лазерном воздействии на смесь оксидов $\mathrm{B}_{2} \mathrm{O}_{3} / \mathrm{ZrO}_{2}$.

\section{ДОСЛІДЖЕННЯ ТЕРМОДЕСОРБЦІЇ ОКСИДНИХ СУМІШЕЙ ПРИ ЛАЗЕРНОМУ ВПЛИВІ}

\section{В.В. Катречко, Д.В. Вінніков, В.Б. Юферов, В.О. Ільічова, О.С. Свічкар, І.В. Буравілов,}

\section{В.Д. Тимофсєв, О.Г. Бобров}

Для вивчення фізико-хімічних процесів, що відбуваються на стадії нагріву магнітоплазмової переробки відпрацьованого ядерного палива (ВЯП), проводиться дослідження процесів термодесорбції оксидів і оксидних сумішей - імітаторів ВЯП при впливі стаціонарного лазерного випромінювання. Проведено попередні експерименти, виконані рентгенодифракційний i енергодисперсійний рентгенівський мікроаналізи плівки, осадженої на підкладку після лазерного впливу на суміш оксидів $\mathrm{B}_{2} \mathrm{O}_{3} / \mathrm{ZrO}_{2}$. 